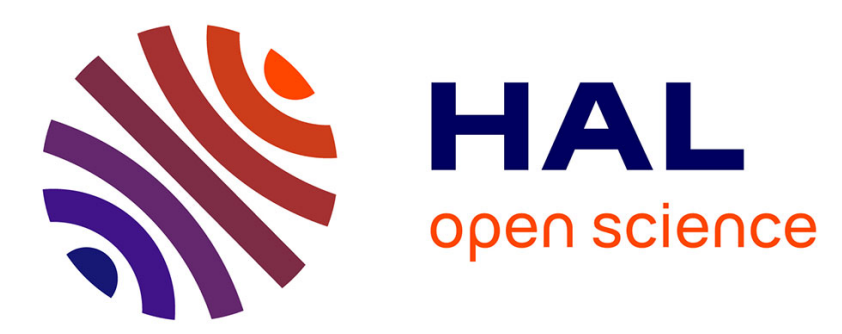

\title{
FT-IR spectroscopy study of HNCO adsorption and hydrolysis over oxide-based samples dedicated to deNO $\mathrm{x}$ processes
}

\author{
M. Barreau, Xavier Courtois, F. Can
}

\section{- To cite this version:}

M. Barreau, Xavier Courtois, F. Can. FT-IR spectroscopy study of HNCO adsorption and hydrolysis over oxide-based samples dedicated to deNO x processes. Applied Catalysis A : General, 2018, 552, pp.147 - 153. 10.1016/j.apcata.2017.12.019 . hal-03110665

\section{HAL Id: hal-03110665 \\ https://hal.science/hal-03110665}

Submitted on 14 Jan 2021

HAL is a multi-disciplinary open access archive for the deposit and dissemination of scientific research documents, whether they are published or not. The documents may come from teaching and research institutions in France or abroad, or from public or private research centers.
L'archive ouverte pluridisciplinaire HAL, est destinée au dépôt et à la diffusion de documents scientifiques de niveau recherche, publiés ou non, émanant des établissements d'enseignement et de recherche français ou étrangers, des laboratoires publics ou privés. 
Applied Catalysis A: General 552 (2018) 147-153

DOI: 10.1016/j.apcata.2017.12.019

\title{
FT-IR spectroscopy study of HNCO adsorption and hydrolysis over oxide-based samples dedicated to deNOx processes.
}

\author{
M. Barreau, X. Courtois* and F. Can* \\ University of Poitiers, CNRS, UMR 7285 \\ Institut de Chimie des Milieux et Matériaux de Poitiers (IC2MP) \\ 4 rue Michel Brunet - TSA 51106 - 86073 Cedex 9, France \\ Fax: (+) +33549453741 \\ E-mail:xavier.courtois@univ-poitiers.fr; fabien.can@univ-poitiers.fr
}

\begin{abstract}
HNCO adsorption monitored by FT-IR spectroscopy was performed over a wide range of oxides from various acid-base and redox properties: $\mathrm{SiO}_{2}, \mathrm{Al}_{2} \mathrm{O}_{3}, \mathrm{TiO}_{2}, \mathrm{ZrO}_{2}, \mathrm{CeO}_{2}, \mathrm{CeO}_{2}-\mathrm{ZrO}_{2}, \mathrm{WO}_{3} / \mathrm{CeO}_{2}-$ $\mathrm{ZrO}_{2}$. HNCO adsorbed dissociatively in the whole studied samples. A correlation with pyridine $v_{8 a}$ wavenumbers revealed that HNCO dissociation mainly involved weak Lewis acid sites (LAS) location. The significant isocyanate adsorption capacity of titania and zirconia was evidenced. HNCO hydrolysis reaction was also investigated. Among the various studied samples, $\mathrm{CeO}_{2}-\mathrm{ZrO}_{2}$ and $\mathrm{WO}_{3} / \mathrm{CeO}_{2}-\mathrm{ZrO}_{2}$ presented the higher HNCO hydrolysis rate, with ammonia formation from room temperature. For all studied samples, $-\mathrm{NCO}$ groups were evidenced as intermediate species of HNCO hydrolysis.
\end{abstract}

Keywords: Isocyanic acid; HNCO hydrolysis; Infrared spectroscopy; oxide-based catalysts; DeNO 


\section{Introduction}

$\mathrm{NO}_{x}$ emissions control from lean-burn engines remains an important challenge for the academic and industrial communities. Among the various processes available to perform NOx ( $\mathrm{NO}$ and $\mathrm{NO}_{2}$ ) abatement, the $\mathrm{NO}_{x}$ storage reduction (NSR) and the selective catalytic reduction (SCR) processes are viable solutions to control $\mathrm{NO}_{\mathrm{x}}$ emission in excess of oxygen. Interestingly, whatever the considered reductants, both technologies involve mechanisms implying the formation of reactive species like $-\mathrm{CN}$ and $-\mathrm{NCO}$, possibly leading to ammonia formation, as key intermediates in the $\mathrm{N}_{2}$ formation. For instance, such species were identified during the lean $\mathrm{NO}_{x}$ reduction by propene over various materials such as perovskites [i], supported transition metals [ii], or supported noble catalysts [iii]. Use of alkanes like propane [iv] or decane [v] also led to $\mathrm{NH}_{3}$ intermediate species over Cu-ZSM-5 exchanged zeolite, as well as during the $\mathrm{NO}_{x}$ reduction process by ethanol over $\mathrm{Ag} / \mathrm{Al}_{2} \mathrm{O}_{3}$ catalyst [vi]. In fact, the direct use of ammonia as reductant is one of the most efficient process to reduce $\mathrm{NO}_{\mathrm{x}}$ from gaseous mixtures containing an excess of oxygen, initially developed for stationary sources. Nevertheless, on boarded ammonia is not suitable (highly toxic and corrosive) and the automotive industry has commonly adopted the safer Urea-SCR technology. Urea $\left(\mathrm{NH}_{2}-\mathrm{CO}-\mathrm{NH}_{2}\right)$ is theoretically decomposed in ammonia via two consecutives reactions: the "urea thermolysis" (Eq. 1) leading to $\mathrm{NH}_{3}$ and $\mathrm{HNCO}$, and the "HNCO hydrolysis" (Eq. 2), leading to the second $\mathrm{NH}_{3}$ molecule.

$$
\begin{aligned}
& \left(\mathrm{NH}_{2}\right) \mathrm{CO}\left(\mathrm{NH}_{2}\right) \rightarrow \mathrm{NH}_{3}+\mathrm{HNCO} \\
& \mathrm{HNCO}+\mathrm{H}_{2} \mathrm{O} \rightarrow \mathrm{NH}_{3}+\mathrm{CO}_{2}
\end{aligned}
$$

The HNCO hydrolysis reaction was previously studied in the literature to ensure the desired production of ammonia [vii]. Recently, the competitive reactivity of the HNCO intermediate species with $\mathrm{NO}_{x}$ was also evidenced during urea-SCR process [viii]. In addition to the desired hydrolysis reaction, it has been showed that $\mathrm{HNCO}$ also competes with $\mathrm{O}_{2}$ and $\mathrm{NO}_{\mathrm{x}}$. During the SCR process, a mix of both NO and $\mathrm{NO}_{2}$ was evidenced to react with $\mathrm{HNCO}$ and contribute to the $\mathrm{NO}_{x}$ reduction, resulting in another deNO pathway [viii].

Finally, mechanistic studies agree that isocyanate species (-NCO) are highly reactive intermediates toward $\mathrm{NO}+\mathrm{O}_{2}$ and/or surface nitrite or nitrate species to produce $\mathrm{N}_{2}$. Consequently, the study of HNCO and $-\mathrm{NCO}$ interactions with surface of catalysts appears essential to highlight the deNO $\mathrm{N}_{\mathrm{x}}$ chemistry. Obviously, despite a major interest due to its importance as an intermediate in virtually all the de $\mathrm{NO}_{x}$ reactions, its surface reactivity is poorly documented. Indeed, HNCO is not available as commercial product and only few means are reported to produce pure gaseous HNCO. In this work, gaseous isocyanic acid was obtained from the decomposition of cyanuric acid, based on the work published by Perry et al. [ix]. The present work is a first step in a deeper characterization of competitive reactions of gaseous HNCO and isocyanates species with the exhaust gas components like $\mathrm{NO}_{x}$. Consequently, the 
HNCO adsorption and hydrolysis reaction was firstly studied by infrared spectroscopy over various oxides selected for their different acid-base and redox properties $\left(\mathrm{SiO}_{2}, \mathrm{Al}_{2} \mathrm{O}_{3}, \mathrm{TiO}_{2}, \mathrm{CeO}_{2}, \mathrm{ZrO}_{2}, \mathrm{CeO}_{2^{-}}\right.$ $\mathrm{ZrO}_{2}$ and supported $\left.\mathrm{WO}_{3} / \mathrm{CeO}_{2}-\mathrm{ZrO}_{2}\right)$.

\section{Material and methods}

Materials used in this study are listed in Table 1. Silica was used as model material for FTIR characterization, alumina as model heterogeneous oxide support, titania and zirconia as model catalysts for urea thermolysis and $\mathrm{HNCO}$ hydrolysis, respectively, ceria and ceria-zirconia $\left(4 \mathrm{w}_{\mathrm{wt}} \%\right.$ of $\mathrm{CeO}_{2}$, thereafter denoted $\mathrm{Ce}-\mathrm{Zr}$ ) as model redox oxides and finally $\mathrm{WO}_{3} / \mathrm{Ce}-\mathrm{Zr}$ as model supported $\mathrm{SCR}$ catalyst [x-xii]. All oxides were provided by chemical companies as reported in Table 1, except for supported $\mathrm{WO}_{3}$ catalyst. For this sample, $\mathrm{Ce}-\mathrm{Zr}$ support (provided by Solvay) was first calcined 4 hours under air at $700^{\circ} \mathrm{C}$. Tungsten $\left(6_{\mathrm{wt}} \% \mathrm{WO}_{3}\right)$ was added by wet impregnation at $60^{\circ} \mathrm{C}$ under continuous agitation using an aqueous solution of ammonium metatungstate. After drying at $80^{\circ} \mathrm{C}$, the preparation was placed in an oven at $120^{\circ} \mathrm{C}$ during a night. Finally all samples were calcined in wet air 4 hours at $700^{\circ} \mathrm{C}$ (heating rate: $\left.5^{\circ} \mathrm{min}^{-1}\right)$.

Specific surface areas were determined by nitrogen adsorption at $77 \mathrm{~K}$ using the BET method (Tristar 3000, Micromeritics). Prior to the $\mathrm{N}_{2}$ physisorption, the samples were degassed under vacuum $2 \mathrm{~h}$ at $250^{\circ} \mathrm{C}$.

Catalysts were characterized by powder X-ray diffraction using a Bruker D5005 diffractometer equipped with a monochromatized $\mathrm{Cu} \mathrm{K}_{\alpha}$ radiation $(\lambda=1.5418 \AA$ ) operated at $40 \mathrm{kV}$ and $30 \mathrm{~mA}$. The diffraction patterns were recorded in the $15-75^{\circ} 2 \theta$ value range, with a step of $0.04^{\circ} \mathrm{sec}^{-1}$ and a step time of $6 \mathrm{~s}$. Crystalline phases were identified by comparison with ICDD database files.

Table 1. Physical properties of the studied samples.

\begin{tabular}{|c|c|c|c|}
\hline samples & provider & $\begin{array}{l}\text { B.E.T surface } \\
\text { area }\left(\mathrm{m}^{2} \mathrm{~g}^{-1}\right)\end{array}$ & $\begin{array}{c}\mathrm{XRD} \\
{[\mathrm{ICDD}]}\end{array}$ \\
\hline $\mathrm{SiO}_{2}$ & Aerosil 90, Degussa & 38 & \\
\hline $\mathrm{Al}_{2} \mathrm{O}_{3}$ & GOD 215, Axens & 176 & $00-050-0741(I)$ \\
\hline $\mathrm{TiO}_{2}$ & Aldrich & 13 & $\begin{array}{l}96 \% \text { rutile } \\
00-034-0180 \\
4 \% \text { anatase } \\
21-1272\end{array}$ \\
\hline $\mathrm{CeO}_{2}$ & HAS 1A, Solvay & 43 & $34-0394$ \\
\hline $\mathrm{ZrO}_{2}$ & Solvay & 16 & $79-1766$ \\
\hline $\mathrm{CeO}_{2}-\mathrm{ZrO}_{2}(\mathrm{Ce}-\mathrm{Zr})$ & Solvay & 73 & $38-1436$ \\
\hline $\mathrm{WO}_{3} / \mathrm{Ce}-\mathrm{Zr}$ & $\begin{array}{l}\text { Wet impregnation of } \\
\left(\mathrm{NH}_{4}\right)_{10} \mathrm{~W}_{12} \mathrm{O}_{41} \cdot 5 \mathrm{H}_{2} \mathrm{O} \text { salt, Alfa Aesar }\end{array}$ & 52 & $38-1436$ \\
\hline
\end{tabular}


The surface acidity of materials was evaluated by pyridine adsorption monitored by IR spectroscopy. IR spectra were collected with a Nexus Nicolet spectrometer equipped with a DTGS detector (Deuterium TriGlyceride Sulfur) and a $\mathrm{KBr}$ beam splitter. IR spectra were recorded with a resolution of $4 \mathrm{~cm}^{-1}$ and 64 scans. The presented spectra were normalized to a disc of $10 \mathrm{mg} / \mathrm{cm}^{2}$. After sample activation at $400{ }^{\circ} \mathrm{C}$ (residual pressure of about $5.10^{-5} \mathrm{hPa}$ ), pyridine was adsorbed (200 $\mathrm{Pa}$ at equilibrium) at room temperature (RT). Desorption was performed up to $400^{\circ} \mathrm{C}$, by temperature step of $50^{\circ} \mathrm{C}$ under dynamic vacuum.

Interaction of HNCO with oxide solids was studied by transmission mode infrared spectroscopy using a home-made dynamic cell, presented in Fig. 1. The sample holder is associated with a screw which allow to move away the wafer from the infrared beam to record gas phase spectra, while the sample remains in heated zone of the oven. Consequently, the design of this specific IR cell enables to collect IR spectrum of adsorbed species and gaseous compounds at the same temperature $\left(25-400{ }^{\circ} \mathrm{C}\right)$. IR spectra were recorded on a Nicolet 6700 spectrometer equipped with a MCT detector and a $\mathrm{KBr}$ beamsplitter using a resolution of $4 \mathrm{~cm}^{-1}$ and 64 scans. Samples were pressed as self-supported wafer (disc of about $20 \mathrm{mg}, 2 \mathrm{~cm}^{2}$ ) and were firstly treated in situ in the cell at $400{ }^{\circ} \mathrm{C}$ under dynamic vacuum (residual pressure of about $5.10^{-5} \mathrm{hPa}$ ).

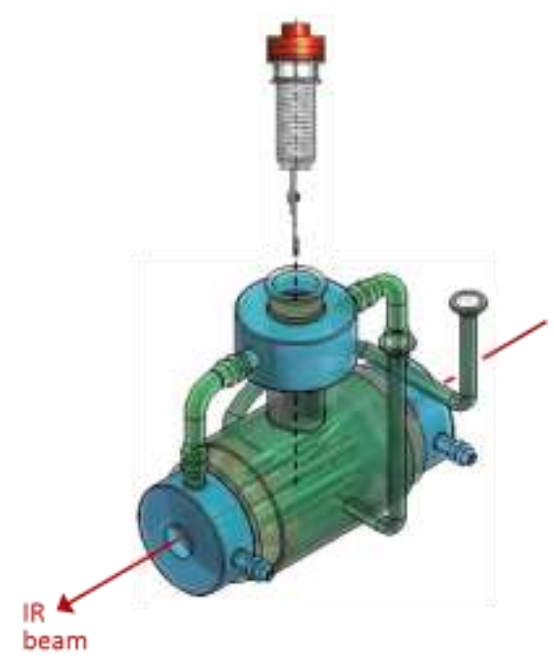

Figure 1. Design of the home-made IR cell for high temperature in situ adsorption of probe molecule. 
Isocyanic acid was produced by depolymerising the cyclic trimer of cyanuric acid (provided by Alfa Aesar, $99 \%$ purity) after heated at $340^{\circ} \mathrm{C}$, in accordance with Eq. 3 [ix].

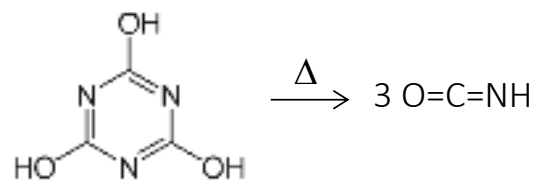

Cyanuric acid, a nontoxic triazine white powder, was placed on a round-bottom flask with a located controlled heated zone connected to the vacuum manifold system of FT-IR experiments. After heated at $340^{\circ} \mathrm{C}$, the equilibrium $\mathrm{HNCO}$ pressure was about $10 \mathrm{hPa}$. Pure isocyanic acid was then expanded in the cell via calibrated doses at RT up to equilibrium by addition of accurately known increments. First, experiments were performed without oxide, in order to ensure a calibration by integrating gaseous HNCO bands. Then, HNCO adsorption was investigated over the studied oxide. At equilibrium (10 hPa), a spectrum of the gas phase was recorded, allowing to determine the amount of HNCO not adsorbed by the oxide tested. By subtracting the remaining amount to the initial amount of HNCO, an absorption capacity of each oxide can be deduced at RT.

A second set of experiments were performed with similar procedure but with water co-adsorption in order to highlight HNCO hydrolysis rate over the studied oxides. In this case, cyanuric acid was heated until the equilibrium HNCO pressure reach $5 \mathrm{hPa}$. Water was then added, by another round-bottom flask, in order to reach a total pressure of $10 \mathrm{hPa}$, corresponding to a $\mathrm{HNCO} / \mathrm{H}_{2} \mathrm{O}$ ratio of 1 . IR spectra of adsorbed species and gas phase were then recorded from RT up to $400{ }^{\circ} \mathrm{C}$, by $25^{\circ} \mathrm{C}$ step.

Presented spectra were normalized to a disc of $10 \mathrm{mg} \mathrm{cm}^{-2}$ and the reference spectra (recorded after calcination at RT) were systematically subtracted to highlight the adsorbed species.

\section{Results and discussion}

\subsection{XRD characterisation}

The XRD patterns (supplementary material, Fig. S1) of selected oxides were consistent with the literature. Alumina material displayed the classical $\gamma-\mathrm{Al}_{2} \mathrm{O}_{3}$ structure [ICDD PDF $\mathrm{n}^{\circ}$ 00-050-0741(I)]. $\mathrm{TiO}_{2}$ mainly indicated rutile crystal phase $\left(2 \theta=27.4,36.1\right.$ and $\left.54.3^{\circ}\right)$ with a low content $(4 \%)$ of anatase mixture $\left(2 \theta=25.4,37.9\right.$ and $\left.48.1^{\circ}\right)$. Pure $\mathrm{CeO}_{2}$ sample calcined at $700{ }^{\circ} \mathrm{C}$ was composed of cubic $\mathrm{CeO}_{2}$ with fluorite structure with diffraction peaks at $2 \theta=28.8,47.7$ and $56.5^{\circ}$. The addition of zirconia to ceria led to a shift of XRD peaks to higher values, and to the appearance characteristic peaks of monoclinic zirconia, at $2 \theta=30.3,50.5$ and $44.8^{\circ}$. Consequently, the Ce- $\operatorname{Zr}(40-60)$ solid showed a broad band which was observed at $2 \theta=29.1^{\circ}$ between pure $\mathrm{c}-\mathrm{CeO}_{2}\left(28.4^{\circ}, \mathrm{JCPDS} 34-0394\right)$ and pure $\mathrm{t}-\mathrm{ZrO}_{2}$ $\left(30.2^{\circ}\right.$, JCPDS 79-1766), which was attributed to $\mathrm{Ce}_{0.5} \mathrm{Zr}_{0.5} \mathrm{O}_{2}$ solid solution due to the replacement of $\mathrm{Ce}^{4+}$ ions $\left(0.97 \AA\right.$ ) by the smaller $\mathrm{Zr}^{4+}$ ions $\left(0.84 \AA\right.$ ). After $\mathrm{WO}_{3}$ impregnation over $\mathrm{Ce}-\mathrm{Zr}$, no modification 
of XRD patterns was observed, with no peaks associated to tungsten species, suggesting a good dispersion of tungsten trioxide phase as previously reported [xii].

\subsection{Surface acidity characterisation}

The surface acidity was determined by IR spectroscopy of adsorbed pyridine, which is one of the most largely used basic probe molecules for surface acidity characterization. Due to the nitrogen electron lone pair, pyridine interacts with acidic centers in a specific way to form (i) the pyridinium ion on protonic sites $\left(\mathrm{PyH}^{+}\right)$and (ii) coordinated species on Lewis acid sites (PyL), giving rise to $v_{8 a}, v_{8 b}, v_{19 a}$ and $v_{19 b}$ ring vibration modes. Pyridine (200 Pa at equilibrium) was adsorbed at room temperature, and then desorbed by temperature steps of $50^{\circ} \mathrm{C}$ up to $450^{\circ} \mathrm{C}$, as previously mentioned in the experimental part. Fig. 2 presents the IR spectra of the samples after pyridine evacuation at $100^{\circ} \mathrm{C}$.

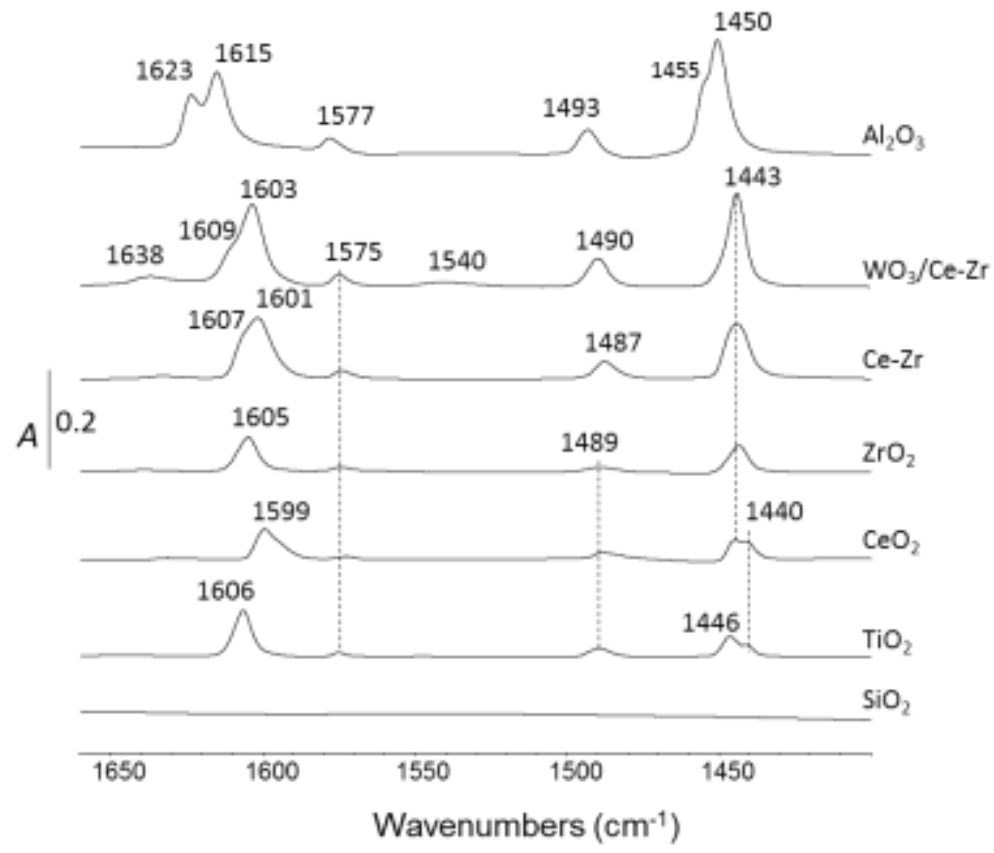

Figure 2. IR spectra of pyridine evacuated at $100^{\circ} \mathrm{C}$ on $\mathrm{SiO}_{2}, \mathrm{TiO}_{2}, \mathrm{CeO}_{2}, \mathrm{ZrO}_{2},\left(\mathrm{WO}_{3}\right) \mathrm{Ce}-\mathrm{Zr}$ and $\mathrm{Al}_{2} \mathrm{O}_{3}$ samples. Spectra are normalized to a disc of $10 \mathrm{mg} \mathrm{cm}^{-2}$.

As expected, the spectrum of $\mathrm{SiO}_{2}$ displays no peak. In most samples, only pyridine coordinated on Lewis acid sites (LAS) is observed. Only $\mathrm{WO}_{3} / \mathrm{Ce}-\mathrm{Zr}$ catalyst exhibited characteristic frequencies of pyridinium surface species by $v_{8 a}$-absorption at $1638 \mathrm{~cm}^{-1}$ in association to $v_{19 b}$-absorption mode at $1540 \mathrm{~cm}^{-1}$ from very weak intensities. These results are in accordance with the literature [xii,xiii] which reported the IR spectra of pyridine adsorbed on tungstated zirconia and $\mathrm{Ce}_{x} \mathrm{Zr}_{1-x} \mathrm{O}_{2}$ mixed-oxide supported $\mathrm{WO}_{3}$ catalysts. In Fig. 2 , bands assignable to $v_{19 b}$ and $v_{8 a}$ mode of coordinatively bound pyridine are observed for $\mathrm{Al}_{2} \mathrm{O}_{3}\left(1450-1455\right.$ and $\left.1615-1623 \mathrm{~cm}^{-1}\right), \mathrm{WO}_{3} / \mathrm{Ce}-\mathrm{Zr}\left(1443\right.$ and $1603-1609 \mathrm{~cm}^{-}$ $\left.{ }^{1}\right), \mathrm{Ce}-\mathrm{Zr}\left(1443\right.$ and $\left.1601-1607 \mathrm{~cm}^{-1}\right), \mathrm{ZrO}_{2}\left(1443\right.$ and $\left.1605 \mathrm{~cm}^{-1}\right), \mathrm{CeO}_{2}\left(1440-1443\right.$ and $\left.1599 \mathrm{~cm}^{-1}\right)$ and $\mathrm{TiO}_{2}$ (1440-1446 and $1606 \mathrm{~cm}^{-1}$ ), which are consistent with the literature [xiv-xvii]. Bands at 1575-1577 
$\mathrm{cm}^{-1}$ and $1487-1493 \mathrm{~cm}^{-1}$ are assigned to $v_{8 b}$ and $v_{19 a}$ ring vibration ( $v_{\mathrm{CCN}}$ stretch), respectively. The higher $v_{8 a}$ frequencies are attributed to strong LAS and correspond to 1623, 1609 and $1607 \mathrm{~cm}^{-1}$ for $\mathrm{Al}_{2} \mathrm{O}_{3}, \mathrm{WO}_{3} / \mathrm{Ce}-\mathrm{Zr}$ and $\mathrm{Ce}-\mathrm{Zr}$, respectively. Consequently, the lower $v_{8 a}$ wavenumbers at 1615,1606 , $1605,1603,1601$ and $1599 \mathrm{~cm}^{-1}$ are assigned to weak LAS and correspond to $\mathrm{Al}_{2} \mathrm{O}_{3}, \mathrm{TiO}_{2}, \mathrm{ZrO}_{2}, \mathrm{WO}_{3} / \mathrm{Ce}-$ $\mathrm{Zr}$, Ce- $\mathrm{Zr}$ and $\mathrm{CeO}_{2}$, respectively. These attributions are used subsequently to highlight isocyanate adsorption sites (section 3.6).

The $v_{19 b}$ mode $\left(1440-1455 \mathrm{~cm}^{-1}\right)$ allows the quantification of the total amount of coordinated pyridine, obtained from the surface area of the corresponding absorption band using its molar coefficient. Tamura et al. verified that the integrated molar extinction coefficients for Lewis acidic metal oxides do not markedly depend on the nature of oxides [xiv]. This indicates that the averaged extinction coefficient for pyridine adsorption on Lewis acid sites $\left(1.73 \mathrm{~cm} \mathrm{\mu mol}^{-1}\right)$ can be used to quantify the LAS concentrations of the whole materials. Consequently, LAS concentration (expressed in $\mu \mathrm{mol} \mathrm{g}^{-1}$ ) is reported in Table 3 for pyridine evacuated at RT and $100^{\circ} \mathrm{C}$ (supplementary material, Fig. S2). For pyridine evacuated at RT, alumina and ceria-zirconia oxides presented the higher LAS concentration, with around 115 and $71 \mu \mathrm{mol} \mathrm{g}$. However, when pyridine was evacuated at higher temperature $\left(100^{\circ} \mathrm{C}\right), \mathrm{WO}_{3} / \mathrm{Ce}-\mathrm{Zr}$ sample exhibited higher acidic sites concentration than Ce-Zr host support. It indicates that deposition of $\mathrm{WO}_{3}$ over ceria-zirconia increased the amount of stronger Lewis acid sites. Due to the variation of specific surface area of various samples, the LAS density (expressed in $\mu \mathrm{mol} \mathrm{m}^{-2}$ ) is reported versus the pyridine temperature evacuation in Fig. 3. From this Figure, the amount and the strength of LAS can be discussed for the whole oxides. It appears that $\mathrm{TiO}_{2}$ and $\mathrm{ZrO}_{2}$ presented the largest density of acid sites, but it rapidly dropped for higher pyridine temperature evacuation. These oxides also presented the lower specific surface area (Table 1). To the opposite, $\mathrm{WO}_{3} / \mathrm{Ce}-\mathrm{Zr}$ and $\mathrm{Al}_{2} \mathrm{O}_{3}$ oxides presented LAS with higher strength, because the declines of adsorbed pyridine with temperature were less pronounced.

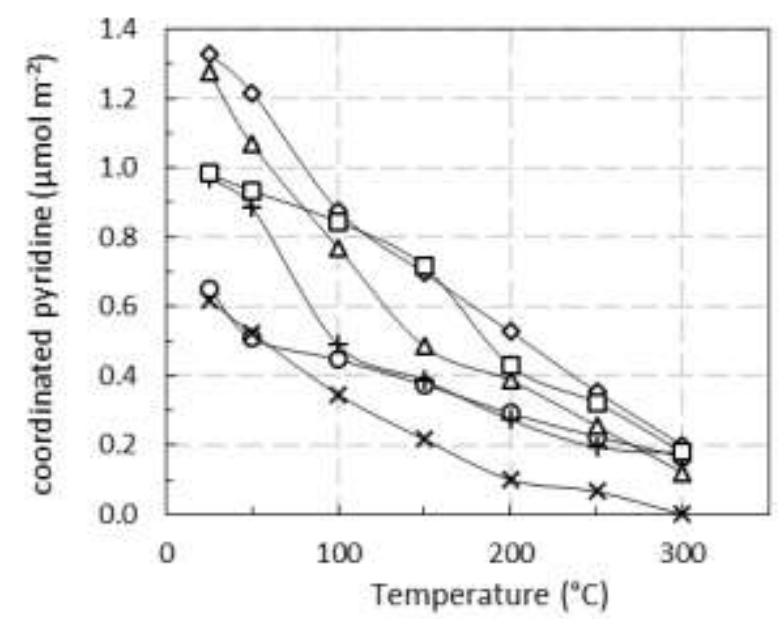

Figure 3. Lewis acid sites concentration ( $\mu \mathrm{mol} \mathrm{m} \mathrm{m}^{-2}$ ) of the metal oxides. $(\mathrm{O}): \mathrm{Al}_{2} \mathrm{O}_{3} ;(\square): \mathrm{WO}_{3} / \mathrm{Ce}-\mathrm{Zr} ;(\times): \mathrm{CeO}_{2} ;(+)$ : $\mathrm{Ce}-\mathrm{Zr} ;(\diamond): \mathrm{TiO}_{2} ;(\triangle): \mathrm{ZrO}_{2}$. 


\subsection{Gaseous isocyanic acid spectrum and calibration}

IR spectra of gaseous HNCO at various equilibrium pressures are presented in Fig. 4 in the 5000-800 $\mathrm{cm}^{-1}$ spectral range. No other compounds than HNCO was observed, illustrating the validity of the $(\mathrm{HNCO})_{3}$ decomposition (eq. 3) to yield pure gaseous isocyanic acid. The IR frequencies assignment are reported in Table 2 and are consistent with the works of Lowenthal et $a$ l. [xviii] and Teles et $a$ l. [xix]. The six vibrational modes of the molecule correspond to three in plane stretches, two in plane bends and one out of plane bend. In the $4500-1000 \mathrm{~cm}^{-1}$ region, only the stretching mode was observable. The three highest energy vibrations are assigned to $\mathrm{v}_{1}\left(\mathrm{~N}-\mathrm{H}\right.$ stretching), $\mathrm{v}_{2}$ (antisymmetric NCO stretching) and $v_{3}$ (symmetric NCO stretching) modes. The $v_{3}$ mode being weakly intense, this band may be also assigned to Fermi resonance split components involving $v_{4}+v_{5}\left(1353 \mathrm{~cm}^{-1}\right.$, Table2).

The integration of IR bands reported in Fig. 4 enables to calibrate the various vibrational modes of gaseous HNCO. Supplementary experiments using addition of accurately known increments were also performed. The intensity of $v_{2}$ bands are plotted in Fig. 5 versus the amount of added isocyanic acid ( $O$ : $\mu \mathrm{mol})$ and the equilibrium pressure of gaseous $\mathrm{HNCO}(\triangle: \mathrm{Pa})$. The straight line indicates a correlation which will be used subsequently to determine the maximum amount of HNCO adsorbed for all the studied oxides, based on the residual pressure of isocyanic acid after adsorption on such materials (section 3.6). An experimental error within $15 \%$ is denoted.

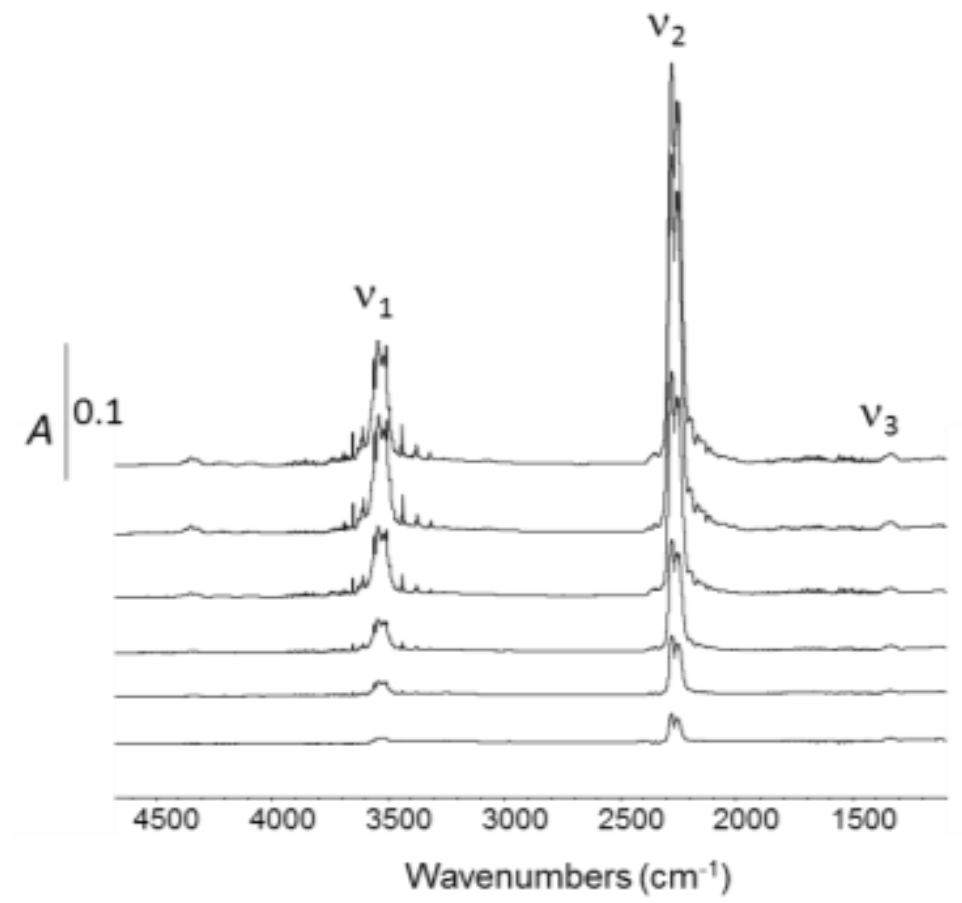

Figure 4. IR spectra of gaseous $\mathrm{HNCO}$ at various equilibrium pressures (from 50 to $400 \mathrm{~Pa}$ ). 
Table 2. IR vibrational assignment of gaseous HNCO [18,19].

\begin{tabular}{lll}
\hline Mode & Assignment & Frequency $\left(\mathrm{cm}^{-1}\right)$ \\
\hline$v_{1}$ & $v_{\mathrm{NH}}$ & 3529 \\
\hline$v_{2}$ & $v_{\mathrm{NCO}}$ asymmetric & 2269 \\
\hline$v_{3}$ & $v_{\mathrm{NCO}}$ symmetric & 1338 \\
\hline$v_{4}$ & $\delta_{\mathrm{HNC}}$ & $(776$, not observed $)$ \\
\hline$v_{5}$ & $\delta_{\mathrm{NCO}}$ & $(577$, not observed $)$ \\
\hline$v_{6}$ & $\delta_{\mathrm{NCO}}$ & $(656$, not observed $)$ \\
\hline
\end{tabular}

Table 3. HNCO storage capacity $\left(\mu \mathrm{mol} \mathrm{g}^{-1}\right)$ and $\mathrm{v}_{8 \mathrm{a}}$ values of coordinated pyridine.

\begin{tabular}{|c|c|c|c|c|c|}
\hline \multirow[b]{3}{*}{ Catalyst } & \multirow{3}{*}{$\begin{array}{c}{[\mathrm{HNCO}]} \\
\left(\mu \mathrm{mol} \mathrm{g}{ }^{-1}\right)^{*}\end{array}$} & \multicolumn{4}{|c|}{ LAS determined from pyridine FT-IR spectra } \\
\hline & & $(\mu \mathrm{mol} g)^{* *}$ & $(\mu \mathrm{mol} g)^{* *}$ & $v_{8 a}\left(\mathrm{~cm}^{-1}\right)$ & $v_{8 a}\left(\mathrm{~cm}^{-1}\right)$ \\
\hline & & RT & $100^{\circ} \mathrm{C}$ & strong LAS & weak LAS \\
\hline $\mathrm{SiO}_{2}$ & 108 & 0.0 & 0.0 & - & - \\
\hline $\mathrm{Al}_{2} \mathrm{O}_{3}$ & 2200 & 114.9 & 78.6 & 1623 & 1615 \\
\hline $\mathrm{ZrO}_{2}$ & 460 & 20.4 & 12.3 & - & 1605 \\
\hline $\mathrm{TiO}_{2}$ & 275 & 17.3 & 11.4 & - & 1606 \\
\hline $\mathrm{CeO}_{2}$ & 650 & 26.6 & 14.9 & - & 1599 \\
\hline $\mathrm{Ce}-\mathrm{Zr}$ & 1175 & 71.0 & 35.7 & 1607 & 1601 \\
\hline $\mathrm{WO}_{3} / \mathrm{Ce}-\mathrm{Zr}$ & 754 & 51.1 & 43.9 & 1609 & 1603 \\
\hline
\end{tabular}

* Determined from residual HNCO pressure at equilibrium (RT).

** Determined from pyridine evacuated at RT or $100^{\circ} \mathrm{C}$.

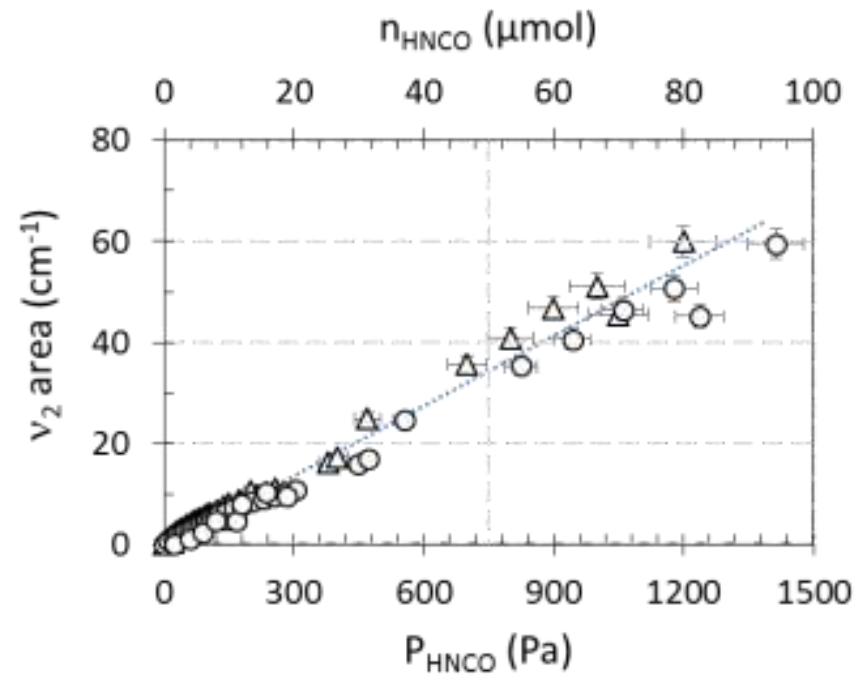

Figure 5. HNCO gaseous calibration for v2 mode. (O): $\mathrm{n}_{\text {HNCO }}(\mu \mathrm{mol}) ;(\triangle)$ : $P_{H N C O}(\mathrm{~Pa})$. 


\subsection{HNCO ad-species over oxides-based samples}

Spectra of adsorbed species over the studied oxide-based samples are presented in Fig. 6 after successive $\mathrm{HNCO}$ additions (up to $15 \mu \mathrm{mol}$ ) at RT. Among the studied oxides, $\mathrm{SiO}_{2}$ was the only material that revealed no band of adsorbed species. Only the gas phase was observed (supplementary material, Fig. S3), in accordance with the previously recorded spectra of gaseous HNCO (Fig. 4).

On the contrary, exposure of $\mathrm{Al}_{2} \mathrm{O}_{3}, \mathrm{ZrO}_{2}, \mathrm{CeO}_{2}, \mathrm{Ce}-\mathrm{Zr}$ and $\mathrm{WO}_{3} / \mathrm{Ce}-\mathrm{Zr}$ samples to controlled increments of HNCO up to $15 \mu \mathrm{mol}$ caused the appearance of bands situated in the $2260-2150 \mathrm{~cm}^{-1}$ spectral region, assigned to isocyanate $(-\mathrm{NCO})$ species adsorbed in various metal centres $\left(\mathrm{M}^{\delta+}-\mathrm{NCO}\right)[\mathrm{Xx}-\mathrm{xxiii}]$. Then, HNCO adsorbs dissociatively on transition metal oxides, leading to isocyanate species bounded to Lewis acid sites (Eq. 4):

$$
\mathrm{HNCO} \rightarrow \mathrm{H}_{(\mathrm{a})}+\mathrm{NCO}_{(\mathrm{a})}
$$

Compared to $v_{2}$ vibrational mode of gaseous $\mathrm{HNCO}$ (Fig. 3), the $-\mathrm{NCO}$ bands were redshifted, resulting in a reduction of the NCO force constant [xxiv]. No other compound was detected in the gas phase, as for instance $\mathrm{CO}$ which could be produced from Eq. 5. We may assume that $\mathrm{N}$ atoms formed from isocyanate decomposition recombined to yield $\mathrm{N}_{2}$ (Eq. 6). However this process was not observed over transition oxide studied in this work. The dissociative adsorption of HNCO toward oxide-based samples is discussed thereafter. The observed shifts of adsorbed isocyanates species are compared to metal oxide properties in section 3.6.

$$
\begin{aligned}
& \mathrm{NCO}_{(\mathrm{a})} \rightarrow \mathrm{CO}_{(\mathrm{g})}+\mathrm{N}_{(\mathrm{a})} \\
& 2 \mathrm{~N}_{(\mathrm{a})} \rightarrow \mathrm{N}_{2(\mathrm{~g})}
\end{aligned}
$$

$\mathrm{Al}_{2} \mathrm{O}_{3}$. The interaction of $-\mathrm{NCO}$ species with alumina is probably the most reported in the literature, and bands at 2259 and $2233 \mathrm{~cm}^{-1}$ are attributed to AlviNCO and to AlıNCO species, respectively $[x x v, x x v i]$. These species were recorded from the first dose of HNCO addition and correspond to the highest wavenumbers observed over all the studied solids.

$\mathrm{ZrO}_{2}$. In agreement with Knozinger et al. [xxvii], surface isocyanate species at $2231 \mathrm{~cm}^{-1}$ are observed over $\mathrm{ZrO}_{2}$. With this solid, it seems that only one adsorption site was effective. The shift to the higher wavenumbers from $2225 \mathrm{~cm}^{-1}$ to $2231 \mathrm{~cm}^{-1}$ is assigned to the consequence of the building up of adsorbate-adsorbate interactions.

$\mathrm{TiO}_{2}$. Over this material, the band at $2223 \mathrm{~cm}^{-1}$ can be attributed to isocyanates groups bounded to $\mathrm{Ti}^{4+}$ in accordance with previous works [xxviii,xxix]. As for $\mathrm{ZrO}_{2}$, a shift was observed from 2195 to 2223 $\mathrm{cm}^{-1}$ together with the increase of the HNCO coverage. 

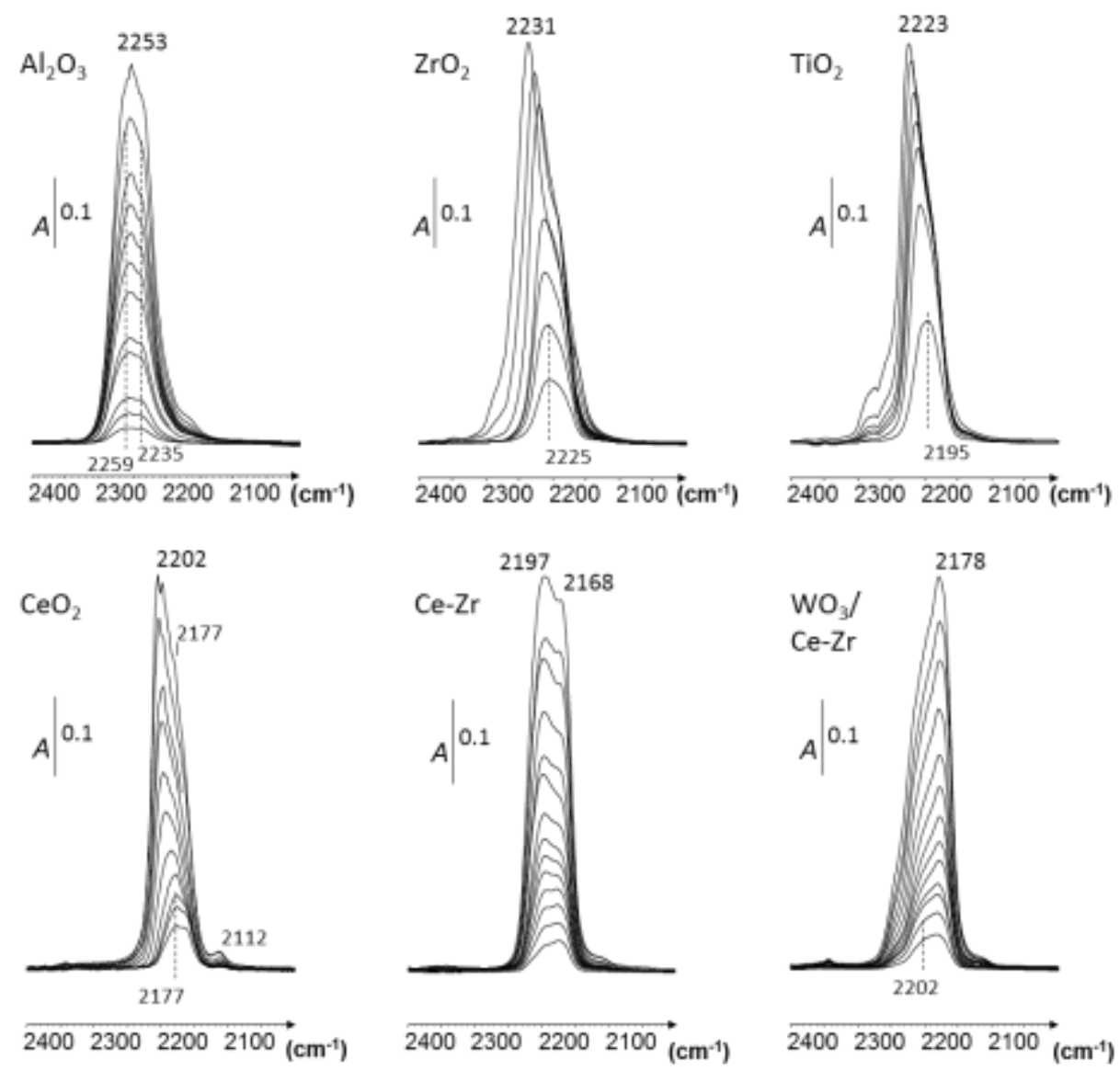

Figure 6. Addition of accurately known increments of HNCO up to $15 \mu \mathrm{mol}$ (at RT) over oxide-based samples. Spectra are normalized to a disc of $10 \mathrm{mg} \mathrm{cm}^{-2}$.

$\mathrm{CeO}_{2}$. Exposure of $\mathrm{CeO}_{2}$ to a very low pressure of $\mathrm{HNCO}$ firstly produced a band centered at $2177 \mathrm{~cm}^{-1}$. The intensities increased with the rise of HNCO pressure, associated with a shift to higher wavenumbers, at $2202 \mathrm{~cm}^{-1}$. Taking into account previous results obtained on ceria [xxx], both bands at 2202 and 2177 $\mathrm{cm}^{-1}$ are attributed to the asymmetric stretch of $\mathrm{NCO}$ species attached to $\mathrm{CeO}_{2}$. The appearance of two bands suggests the presence of two adsorption sites, perhaps $\mathrm{Ce}^{4+}$ and $\mathrm{Ce}^{3+}$. Additionally, the band at $2112 \mathrm{~cm}^{-1}$ is assigned to the ${ }^{2} \mathrm{~F}_{5 / 2} \rightarrow{ }^{2} \mathrm{~F}_{7 / 2}$ electronic transition band of $\mathrm{Ce}^{3+}$ [xxxi] that confirms the presence of both cationic sites $\left(\mathrm{Ce}^{4+} / \mathrm{Ce}^{3+}\right)$.

$\mathrm{CeO}_{2}-\mathrm{ZrO}_{2}$. Exposure of $\mathrm{CeO}_{2}-\mathrm{ZrO}_{2}$ solid solution to $\mathrm{HNCO}$ led to the appearance of $v_{\mathrm{NCO}}$ bands close to cerium oxide, with two adsorption sites. In fact, two bands were observed at $2197 \mathrm{~cm}^{-1}$ and $2168 \mathrm{~cm}^{-}$ ${ }^{1}$ which grew simultaneously with the addition of HNCO. Based on these results and in accordance with the previous attribution over $\mathrm{ZrO}_{2}$, we assigned these bands to the interaction of $-\mathrm{NCO}$ species with two cerium cation, as for ceria.

$\mathrm{WO}_{3} / \mathrm{CeO}_{2}-\mathrm{ZrO}_{2}$. HNCO adsorption over $\mathrm{WO}_{3} / \mathrm{Ce}-\mathrm{Zr}$ firstly revealed a band at $2202 \mathrm{~cm}^{-1}$ which was quickly covered by the band at lower wavenumbers $\left(2178 \mathrm{~cm}^{-1}\right)$. Compared to Ce-Zr host support, the 
band related to $-\mathrm{NCO}$ species at lower wavenumbers $\left(2178 \mathrm{~cm}^{-1}\right)$ presented higher intensity than the high wavenumbers component $\left(2202 \mathrm{~cm}^{-1}\right)$. Additionally, the similar position of this band $\left(2178 \mathrm{~cm}^{-1}\right)$ to that previously observed at the lowest wavenumbers for $\mathrm{CeO}_{2}\left(2177 \mathrm{~cm}^{-1}\right)$ may indicate that $\mathrm{WO}_{3}$ interfered preferentially with one cationic site of ceria support $\left(\mathrm{Ce}^{4+}\right.$ or $\left.\mathrm{Ce}^{3+}\right)$. However, this explanation would require further study.

\subsection{Determination of the molar extinction coefficients $\varepsilon_{N C O}$}

The intensities of the absorbance bands of the infrared spectra in the transmission mode depend on the amount of vibrating species through the optical path of the infrared beam. On homogeneous sample, IR absorbance can be used for quantitative analyses. The equation used is similar to the BeerLambert law for a solution. The absorbance integrated intensity for a band is named I, as reported by Eq. 7:

$$
\mathrm{I}=\int_{v 1}^{v 2} A(v) \mathrm{d} v=\varepsilon \mathrm{d}(\mathrm{n} / \mathrm{Sd})=\varepsilon\left(\frac{\mathrm{n}}{\mathrm{S}}\right)
$$

where $A(v), v, n, S$ and $d$ denote the absorbance, the wavenumber, the number of vibrators, the area of the oxide disc and the thickness of the wafer assumed to correspond to the optical pathway [xxxii], respectively. From the addition of accurately known increments of HNCO previously reported in Fig. 6, the corresponding integrated intensities of $v_{\mathrm{NCO}}$ band related to the isocyanate adsorbed species are plotted in Fig. 7 versus the amount of added $\mathrm{HNCO}\left(\mu \mathrm{mol} \mathrm{cm}^{-2}\right)$. The apparent molar extinction coefficient of the $v_{2}$ mode of HNCO $\left(\varepsilon_{N C O}\right)$ at RT is deduced from the obtained slopes as $\varepsilon=\mathrm{S} \frac{d(\mathrm{I})}{d \mathrm{n}}(\varepsilon$ in $\mu \mathrm{mol}^{-1} \mathrm{~cm}$ ). Fig. 7 reveals some variations in the observed slope depending on the considered sample. However, the averaged extinction coefficient is $11.8 \pm 1.8 \mathrm{~cm} \mathrm{umol}^{-1}$.

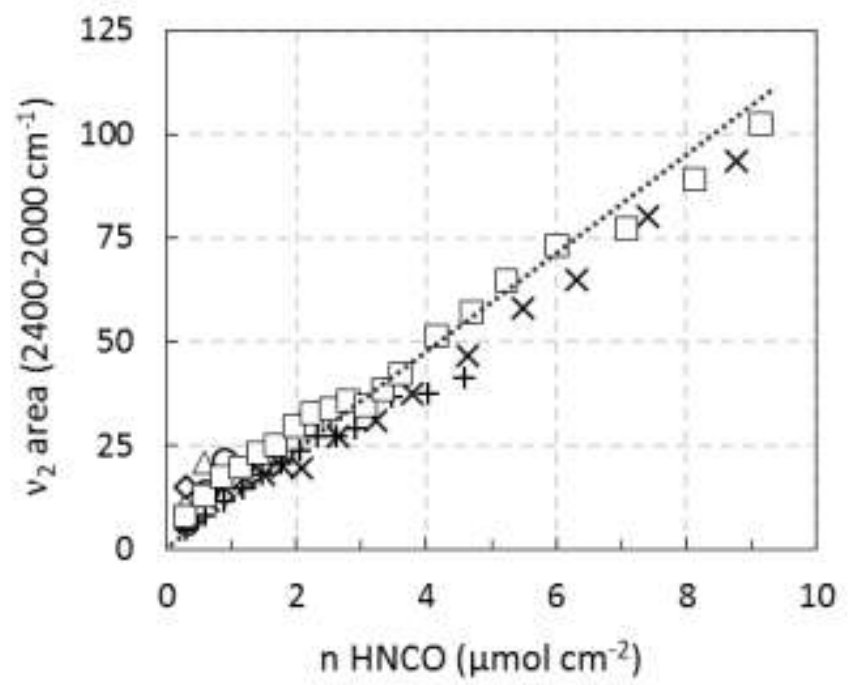

Figure 7. Integrated intensity of the $v_{2}$ mode of $\mathrm{HNCO}$ versus addition of increments of $\mathrm{HNCO}\left(\mu \mathrm{mol} \mathrm{cm}^{-2}\right)$. $(O): \mathrm{Al}_{2} \mathrm{O}_{3} ;(\square): \mathrm{WO}_{3} / \mathrm{Ce}-\mathrm{Zr} ;(\times): \mathrm{CeO}_{2} ;(+): \mathrm{Ce}-\mathrm{Zr} ;(\diamond): \mathrm{TiO}_{2} ;(\triangle): \mathrm{ZrO}_{2}$. 
Morterra et al. [xxxiii] presented a critical use of molar absorption coefficients for adsorbed species. They checked the validity of equations of the Beer-Lambert law for heterogeneous systems like silica for methanol adsorption. For instance, they reported that molar absorption coefficient values greatly vary depending on the silica provider. The suggested reasons were the catalyst specific surface area, the sample thickness, the surface dehydration level and the diffusion properties of the adsorbent. Consequently, the use of absorption coefficients in the Beer-Lambert law is not rigorous in the case of powder samples, since the absorption coefficients for adsorbed species depend on the optical properties of the solid, on the experimental conditions, and on the interaction between the solid and the adsorbed molecule. For instance, in our case, the studied samples presented very different specific surface area from 13 to $176 \mathrm{~m}^{2} \mathrm{~g}^{-1}$ for $\mathrm{TiO}_{2}$ and $\mathrm{Al}_{2} \mathrm{O}_{3}$, respectively. This important variation can explain the measured deviations from the calculation of the molar absorption coefficients.

In addition, it is well known that the molar extinction coefficients also depends on the adsorbing sites. The use of a global HNCO molar extinction coefficient regardless of multiple HNCO adsorption sites can lead to incorrect site quantification. As a consequence, the advanced values should be interpreted cautiously and the reported data have to be completed by coupling infrared spectroscopy and in situ thermogravimetry experiments for instance. Nevertheless, obtained extinction coefficients from HNCO adsorption appeared rather close together and the decomposition of cyanuric acid to yield pure gaseous isocyanic acid is a first step of deeper analytical works for in situ infrared studies of isocyanate species reactivity.

\subsection{HNCO adsorption capacity, dissociative adsorption}

In this section the maximum HNCO adsorption capacity of the various studied oxides was measured. The quantification of adsorbed species cannot be performed using the apparent molar coefficient due to the saturation of the detector for samples that displayed important HNCO adsorption abilities such as $\mathrm{Al}_{2} \mathrm{O}_{3}, \mathrm{CeO}_{2}, \mathrm{Ce}-\mathrm{Zr}$ and $\mathrm{WO}_{3} / \mathrm{Ce}-\mathrm{Zr}$. Consequently, a more accurate estimation of the HNCO adsorption capacities resulted in the equilibrium pressure measurement between the relaxed amount in the cell and that obtained in the presence of the sample. From the previously calculated gas phase calibration (section 3.3, Fig. 5), the adsorbed amount can be determined.

Results reported in Table 3 illustrate the remarkable $\mathrm{HNCO}$ adsorption capacity of $\mathrm{Al}_{2} \mathrm{O}_{3}$ with around $2200 \mu \mathrm{mol} \mathrm{g} \mathrm{g}^{-1}$. However, this oxide also exhibited higher specific surface area, with $176 \mathrm{~m}^{2} \mathrm{~g}^{-1}$. Due to the important variation of the B.E.T values of the whole studied samples, the HNCO adsorption amount was correlated to the acid sites density $\left(\mu \mathrm{mol} \mathrm{m}^{-2}\right.$ ), determined from pyridine adsorption (Fig. 3). It appears in Fig. 8A that the higher the LAS density, the higher the HNCO adsorption capacity. This result confirms that HNCO adsorption abilities was directly correlated to LAS, as previously proposed by 
Solymosi et al. [xxi,xxii] (supplementary material, Fig. S4). Additionally, it is worth noting that acidic properties were determined from pyridine adsorbed under dynamic vacuum, whereas HNCO adsorption abilities were provided at equilibrium pressure. This explains the quantitative divergence of Fig. 8A. Nevertheless, catalysts behaviours are clearly distinguishable despite the experimental error, demonstrating the higher $\mathrm{HNCO}$ adsorption density for $\mathrm{TiO}_{2}$ and $\mathrm{ZrO}_{2}$ materials.

Finally, the higher wavenumbers of the $v_{2}$ mode of adsorbed isocyanates (Fig. 6) is reported versus the $v_{8 a}$ ring vibration of coordinated pyridine in Fig 8B. Both weak and strong LAS (Table 3) previously discussed in Fig. 2 are considered. It appears that HNCO dissociative adsorption mainly involves weak LAS location. Besides, due to the important wavenumbers variation of the $v_{a s(\mathrm{NCO})}$ band depending on the studied material (2289-2177 $\left.\mathrm{cm}^{-1}\right)$ together with the dissociative adsorption of HNCO, it appears that isocyanic acid could be an appropriate probe molecule for weak Lewis acid-base pairs.
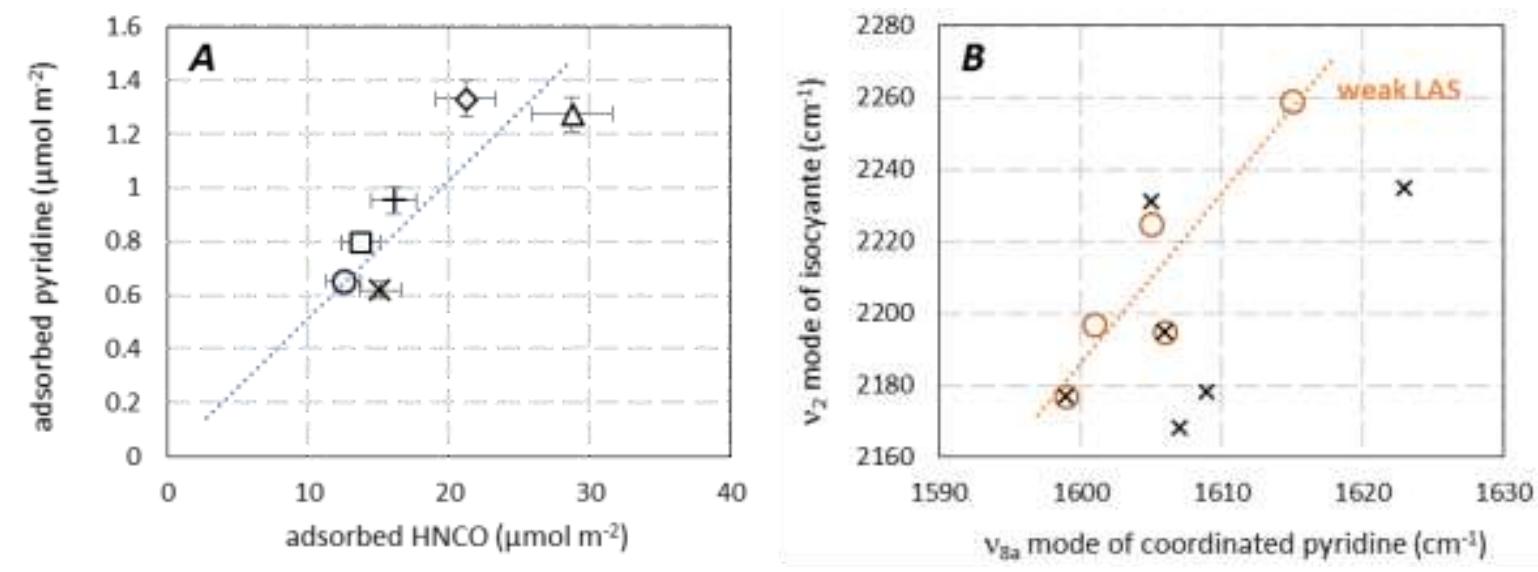

Figure 8. A: Relationship between LAS density determined from pyridine evacuated at RT and HNCO adsorption capacity. B: Relationship between the $v_{2}$ mode of isocyanate and the $v_{8 a}$ mode of coordinated pyridine $(O$ : weak LAS; $\times$ : strong LAS).

$(\mathrm{O}): \mathrm{Al}_{2} \mathrm{O}_{3} ;(\square): \mathrm{WO}_{3} / \mathrm{Ce}-\mathrm{Zr} ;(\times): \mathrm{CeO}_{2} ;(+): \mathrm{Ce}-\mathrm{Zr} ;(\diamond): \mathrm{TiO}_{2} ;(\triangle): \mathrm{ZrO}_{2}$.

\subsection{HNCO hydrolysis rate}

HNCO hydrolysis is expected to produce ammonia in the NOx SCR by urea process. To study the HNCO hydrolysis rate over the oxide-based samples, $\mathrm{H}_{2} \mathrm{O}$ was added on the IR cell together with HNCO, as described in the experimental part. Both surface and gaseous IR spectra were recorded every $25^{\circ} \mathrm{C}$ from $25^{\circ} \mathrm{C}$ up to $400^{\circ} \mathrm{C}$.

Examples of gaseous spectra are reported in Fig. 9A for alumina sample. Spectra are characterized by IR bands characteristic of $\mathrm{HNCO}\left(\mathrm{vas}_{\mathrm{N}(\mathrm{NCO})}\right), \mathrm{CO}_{2}\left(\mathrm{v}_{\mathrm{as}(\mathrm{OCO})}\right), \mathrm{H}_{2} \mathrm{O}\left(\delta_{(\mathrm{OH})}\right)$ and $\mathrm{NH}_{3}\left(\boldsymbol{\delta}_{(\mathrm{NH})}\right)$ species. In this sample, $\mathrm{HNCO}$ seemed fully consumed at around $150{ }^{\circ} \mathrm{C}$, concomitantly with $\mathrm{NH}_{3}$ and $\mathrm{CO}_{2}$ formation, whose maximum concentration was reached before $200^{\circ} \mathrm{C}$. These results highlight the HNCO hydrolysis 
reaction (Eq. 2). Besides, IR spectra of adsorbed species (supplementary material, Fig. S5) revealed that -NCO adsorbates were concomitantly consumed. This result suggests that hydrolysis of HNCO involves isocyanate species as intermediate. In fact, two mechanisms can be differentiated to highlight ammonia production, with the involvement or not of adsorbed intermediates. Unland [xxxiv] suggested that $\mathrm{NH}_{3}$ is produced by HNCO hydrolysis, possibly via carbamic acid formation (Eq. 8). In this case, -NCO species are not suspected to be involved in the mechanism of $\mathrm{NH}_{3}$ formation.

$$
\begin{aligned}
& \mathrm{HNCO}+\mathrm{H}_{2} \mathrm{O} \rightarrow\left(\mathrm{H}_{2} \mathrm{NCOOH}\right) \rightarrow \mathrm{NH}_{3}+\mathrm{CO}_{2} \\
& \mathrm{NCO}_{(\mathrm{a})}+\mathrm{H}_{2} \mathrm{O} \rightarrow \mathrm{NH}_{2(\mathrm{a})}+\mathrm{CO}_{2} \\
& \mathrm{NH}_{2(\mathrm{a})}+\mathrm{H}_{2} \mathrm{O} \rightarrow \mathrm{OH}_{(\mathrm{a})}+\mathrm{NH}_{3}
\end{aligned}
$$

In this work, it is proposed that HNCO hydrolysis rather proceeds via a surface reaction of adsorbed isocyanate species, as illustrated by Eq. 9 and Eq. 10 resulting in the global following reaction (Eq. 11):

$$
\mathrm{NCO}_{(\mathrm{a})}+2 \mathrm{H}_{2} \mathrm{O} \rightarrow \mathrm{NH}_{3}+\mathrm{CO}_{2}+\mathrm{OH}_{(\mathrm{a})}
$$

The intensity of the $\mathrm{NH}_{3}$ band can be monitored versus the temperature. Fig $9 \mathrm{~B}$ shows that $\mathrm{HNCO}$ hydrolysis rate depended on the involved solid. All catalysts were fully selective in ammonia production. No other compounds than $\mathrm{NH}_{3}$ and $\mathrm{CO}_{2}$ were observed. $\mathrm{HNCO}$ was fully hydrolysed at $175-200{ }^{\circ} \mathrm{C}$ for all catalysts studied, but some oxides hydrolysed isocyanic acid already at $25^{\circ} \mathrm{C}$, such as $\mathrm{CeO}_{2}, \mathrm{WO}_{3} / \mathrm{Ce}-\mathrm{Zr}$ and Ce-Zr which presented remarkable activities for HNCO hydrolysis. The following activity order was then obtained: $\mathrm{WO}_{3} / \mathrm{Ce}-\mathrm{Zr}=\mathrm{Ce}-\mathrm{Zr}>\mathrm{CeO}_{2}>\mathrm{ZrO}_{2}>\mathrm{TiO}_{2}>\mathrm{Al}_{2} \mathrm{O}_{3} \gg \mathrm{SiO}_{2}$. Note that Kröcher et al. [xxxv] proposed the following ranking: $\mathrm{ZrO}_{2}>\mathrm{TiO}_{2}>\mathrm{Al}_{2} \mathrm{O}_{3}>\mathrm{H}-\mathrm{ZSM}-5>>\mathrm{SiO}_{2}$, which is consistent with our results.
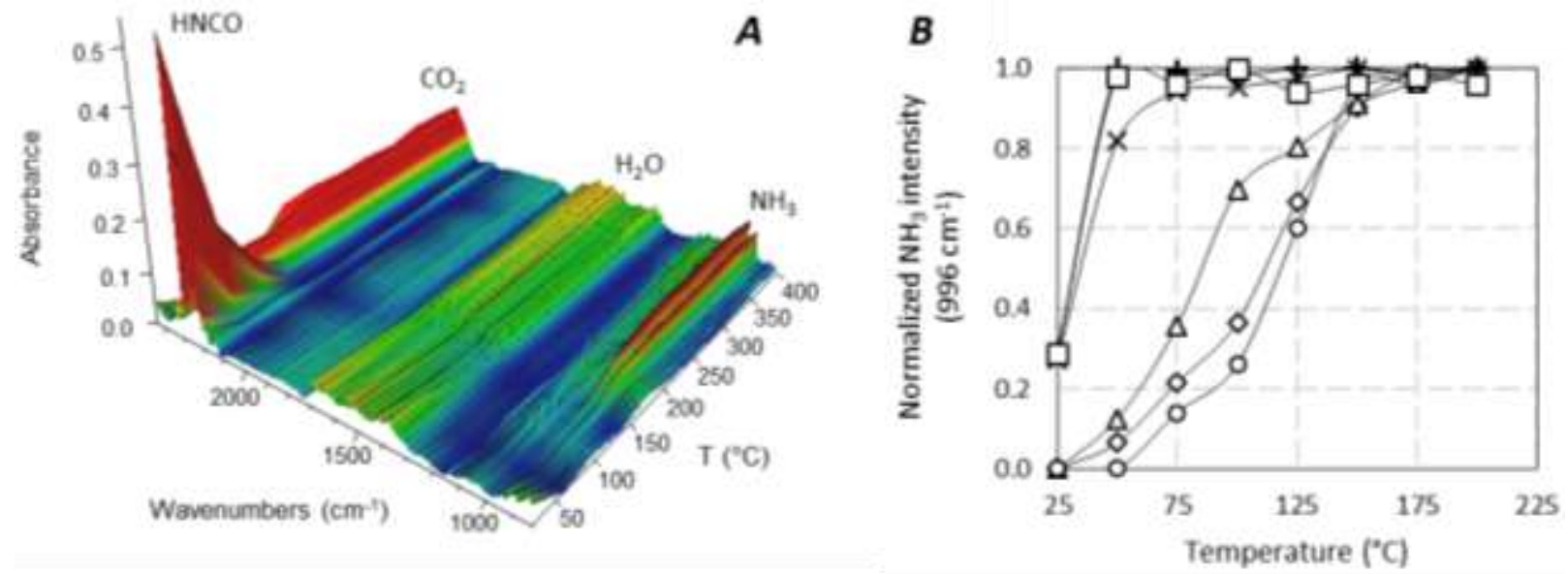

Figure 9. Gaseous IR spectra of $\mathrm{HNCO}$ hydrolysis reaction over $\mathrm{Al}_{2} \mathrm{O}_{3}$ from $25^{\circ} \mathrm{C}$ to $400^{\circ} \mathrm{C}(\mathrm{A})$; normalized evolution of the intensity of the $\mathrm{NH}_{3}$ band at $966 \mathrm{~cm}^{-1}$ versus temperature for: $(\mathrm{O}): \mathrm{Al}_{2} \mathrm{O}_{3} ;(\square): \mathrm{WO}_{3} / \mathrm{Ce}-\mathrm{Zr} ;(X)$ : $\mathrm{CeO}_{2} ;(+)$ : $\mathrm{Ce}-\mathrm{Zr} ;(\diamond): \mathrm{TiO}_{2} ;(\triangle): \mathrm{ZrO}_{2}$. 


\section{Conclusion}

Isocyanate species (-NCO) are well recognized as major intermediate in numerous de $\mathrm{NO}_{x}$ reactions, although few studies are openly devoted to their direct characterization. This work is a first step to a deeper knowledge of HNCO and adsorbed -NCO species reactivity by means of in situ FTIR spectroscopy. Pure gaseous isocyanic acid was obtained by depolymerising the cyclic trimer of cyanuric acid that allows HNCO adsorption monitored by FT-IR spectroscopy over a wide range of common oxides with various acid-base and redox properties: $\mathrm{SiO}_{2}, \mathrm{Al}_{2} \mathrm{O}_{3}, \mathrm{TiO}_{2}, \mathrm{ZrO}, \mathrm{CeO}_{2}, \mathrm{CeO}_{2}-\mathrm{ZrO}_{2}, \mathrm{WO}_{3} / \mathrm{CeO}_{2}-\mathrm{ZrO}_{2}$. This study pointed out that HNCO adsorption is strongly dependent on transition metal adsorption sites, but also on the oxidation state of this latter. Molar extinction coefficients of adsorbed isocyanates species are proposed. They have to be used carefully, especially due to different specific surface area and multiple HNCO adsorption sites of the whole samples. Additionally, this work reveals the remarkable ability of $\mathrm{TiO}_{2}$ and $\mathrm{ZrO}_{2}$ solids to adsorb -NCO species. Co-adsorption of water illustrates the HNCO hydrolysis reaction rate, with an impressive reactivity of $\mathrm{WO}_{3} / \mathrm{Ce}-\mathrm{Zr}, \mathrm{Ce}-\mathrm{Zr}$ and $\mathrm{CeO}_{2}$ materials to yield $\mathrm{NH}_{3}$ and $\mathrm{CO}_{2}$ at $25^{\circ} \mathrm{C}$. For all oxide catalysts, $-\mathrm{NCO}$ species are reported as intermediate compounds of HNCO hydrolysis.

\section{Acknowledgement}

The authors thank the European communities (FEDER) and the "Région Nouvelle Aquitaine" for the financial support. Authors thank the "Engineering, development and technical support" division of the IC2MP laboratory for the implementation of the experimental analysis device: Michel Chauveau, JeanJacques Colin, Claude Veit, Claude Rouvier and Bertrand Leroux. 


\section{Supplementary Material}

\section{XRD characterisation}

XRD patterns of the whole studied samples are presented in Fig. S1. Accordingly to the literature, alumina displays the classical $\gamma-\mathrm{Al}_{2} \mathrm{O}_{3}$ structure. $\mathrm{TiO}_{2}$ mainly indicates rutile crystal phase $(2 \theta=27.4,36.1$ and $\left.54.3^{\circ}\right)$ with a low content (4\%) of anatase mixture $\left(2 \theta=25.4,37.9\right.$ and $\left.48.1^{\circ}\right)$. Pure $\mathrm{CeO}_{2}$ sample is composed of cubic $\mathrm{CeO}_{2}$ with fluorite structure at $2 \theta=28.8,47.7$ and $56.5^{\circ}$. The addition of zirconia to ceria led to a shift of XRD peaks to higher values, and to the appearance characteristic peaks of monoclinic zirconia, at $2 \theta=30.3,50.5$ and $44.8^{\circ}$. Consequently, the Ce- $\operatorname{Zr}(40-60)$ solid showed a broad band, observed at $2 \theta=29.1^{\circ}$, between pure c- $\mathrm{CeO}_{2}\left(28.4^{\circ}, \mathrm{JCPDS} 34-0394\right)$ and pure t- $\mathrm{ZrO}_{2}\left(30.2^{\circ}, \mathrm{JCPDS}\right.$ 79-1766), which was attributed to $\mathrm{Ce}_{0.5} \mathrm{Zr}_{0.5} \mathrm{O}_{2}$ solid solution due to the replacement of $\mathrm{Ce}^{4+}$ ions (0.97 $\AA$ ) by the smaller $\mathrm{Zr}^{4+}$ ions $\left(0.84 \AA\right.$ ). After $\mathrm{WO}_{3}$ impregnation over $\mathrm{Ce}-\mathrm{Zr}$, no modification of XRD patterns is observed, with no $\mathrm{WO}_{3} \mathrm{XRD}$ peaks detected, suggesting a good dispersion of tungsten trioxide phase.

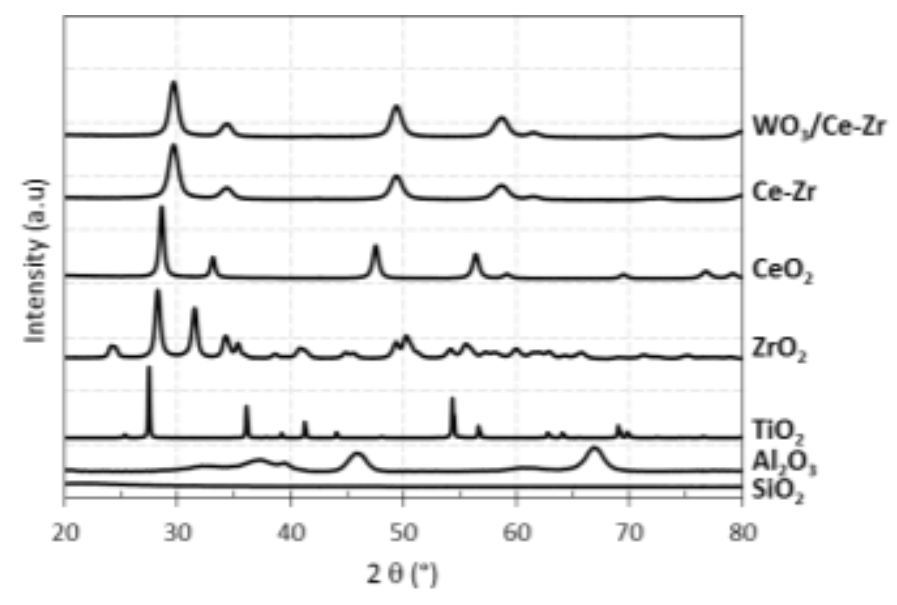

Figure S1. XRD patterns of oxides samples.

\section{Surface acidity characterisation}

Based on pyridine adsorption monitored by IR spectroscopy, the Lewis acid sites (LAS) concentration is calculated using the $v_{19 b}$ mode of the ring vibration ( $v_{\mathrm{CCN}}$ stretch) of coordinated pyridine (1440-1455 $\mathrm{cm}^{-1}$ ). The LAS concentration (expressed in $\mu \mathrm{mol} \mathrm{g} \mathrm{g}^{-1}$ ) of $\mathrm{Al}_{2} \mathrm{O}_{3}, \mathrm{TiO}_{2}, \mathrm{ZrO}_{2}, \mathrm{CeO}_{2}, \mathrm{Ce}-\mathrm{Zr}$ and $\mathrm{WO}_{3} / \mathrm{Ce}-\mathrm{Zr}$ samples is reported versus the pyridine temperature evacuation in Fig. S2.

It clearly appears that alumina present the higher LAS concentration of the whole studied catalysts. To the opposite, $\mathrm{TiO}_{2}, \mathrm{ZrO}_{2}$ and $\mathrm{CeO}_{2}$ oxides are characterised by low Lewis acid sites concentration. The addition of ceria to zirconia enhance the acidic properties of the $\mathrm{Ce}-\mathrm{Zr}$ sample compared to pure $\mathrm{CeO}_{2}$ or $\mathrm{ZrO}_{2}$ oxides. Additionally, the impregnation of $\mathrm{WO}_{3}$ to $\mathrm{Ce}-\mathrm{Zr}$ increases the strength of LAS with an improvement of coordinated pyridine concentration for high temperature evacuation compared to CeZr host support. 


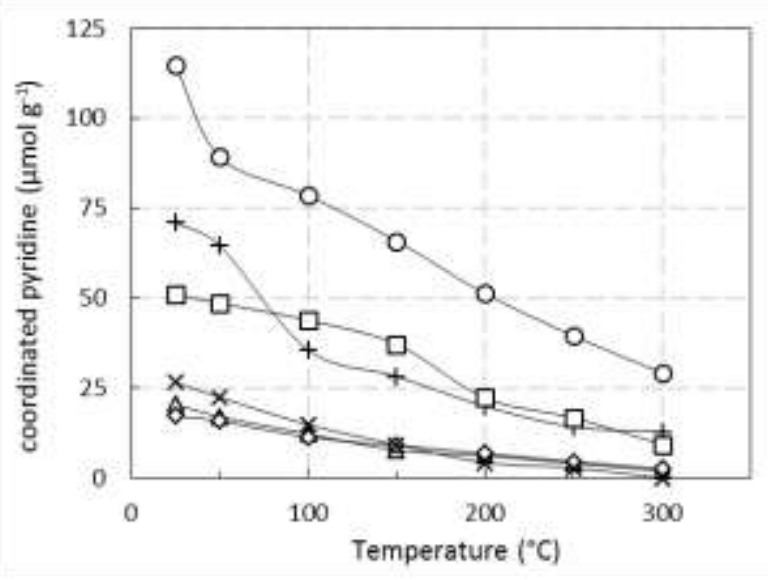

Figure S2. Lewis acid sites concentration $\left(\mu \mathrm{mol} \mathrm{g}^{-1}\right.$ ) of the metal oxides. $(\mathrm{O}): \mathrm{Al}_{2} \mathrm{O}_{3} ;(\square): \mathrm{WO}_{3} / \mathrm{Ce}-\mathrm{Zr}$; $(\times): \mathrm{CeO}_{2} ;(+): \mathrm{Ce}-\mathrm{Zr} ;(\diamond): \mathrm{TiO}_{2} ;(\triangle): \mathrm{ZrO}_{2}$.

\section{3. $\mathrm{HNCO}$ ad-species over $\mathrm{SiO}_{2}$}

Spectrum of adsorbed species after HNCO additions (10 $\mu \mathrm{mol})$ at RT (spectra are normalised to a disc of $10 \mathrm{mg} \mathrm{cm}^{-2}$ ) reveal that $\mathrm{SiO}_{2}$ present no band of adsorbed species. Only the gas phase was observed as reported in Fig. S3. The band at $2269 \mathrm{~cm}^{-1}$ is assigned to the $v_{2}$ mode of the asymmetric $v_{\mathrm{Nco}}$ vibration of gaseous HNCO.

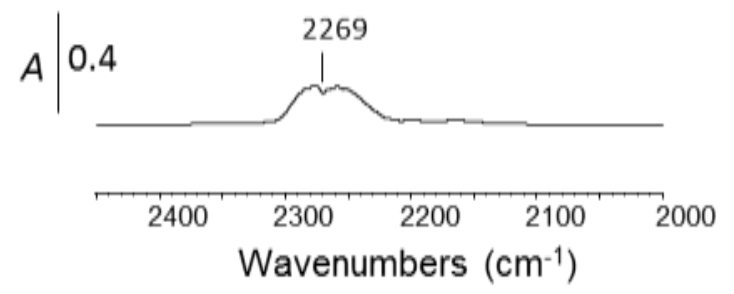

Figure S3. IR spectrum of HNCO adsorption (10 $\mu \mathrm{mol})$ over $\mathrm{SiO}_{2}$.

\section{HNCO adsorption capacity}

The HNCO adsorption capacity of the whole studied sample $\left(\mathrm{Al}_{2} \mathrm{O}_{3}, \mathrm{TiO}_{2}, \mathrm{ZrO}_{2}, \mathrm{CeO}_{2}, \mathrm{Ce}-\mathrm{Zr}\right.$ and $\mathrm{WO}_{3} / \mathrm{Ce}-\mathrm{Zr}$ ) was evaluated and compared to acidic sites concentration $\left(\mu \mathrm{mol} \mathrm{g}{ }^{-1}\right.$ ), determined from pyridine evacuation (Fig. S2). Results reported in Fig S4 indicate that higher the Lewis acid sites concentration, higher the HNCO adsorption capacity. 


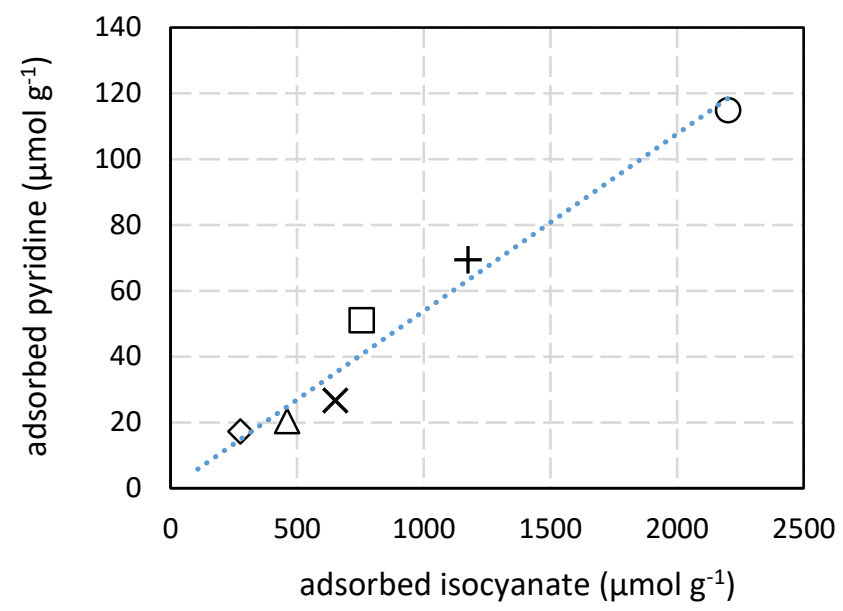

Figure S4. Relationship between LAS concentration determined from pyridine evacuated at RT and HNCO adsorption capacity $\left(\mu \mathrm{mol} g^{-1}\right) \cdot(\bigcirc): \mathrm{Al}_{2} \mathrm{O}_{3} ;(\square): \mathrm{WO}_{3} / \mathrm{Ce}-\mathrm{Zr} ;(\times): \mathrm{CeO}_{2} ;(+): \mathrm{Ce}-\mathrm{Zr} ;(\diamond): \mathrm{TiO}_{2} ;(\triangle)$ : $\mathrm{ZrO}_{2}$.

\section{HNCO hydrolysis}

The HNCO hydrolysis reaction is studied by expanding $\mathrm{H}_{2} \mathrm{O}$ on the IR cell together with HNCO. Surface and gaseous IR spectra were successively recorded from 25 up to $400{ }^{\circ} \mathrm{C}$ by $25^{\circ} \mathrm{C}$ step.

$A$

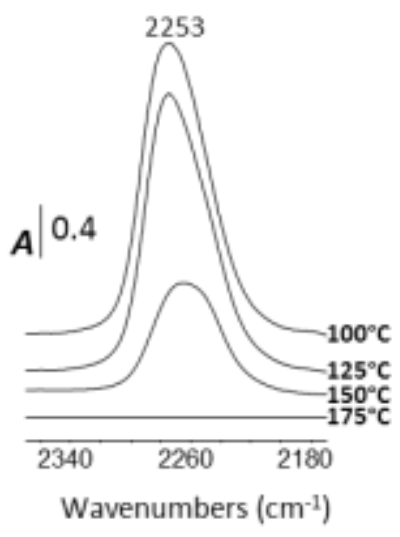

B

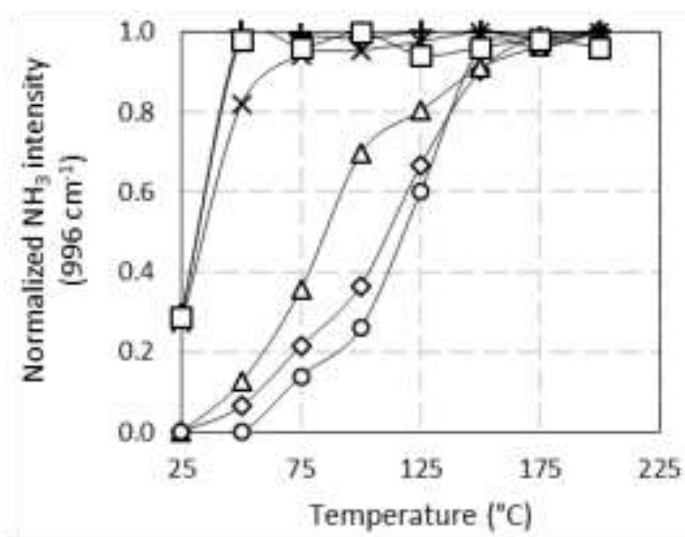

Figure S5. IR spectra of adsorbed species of $\mathrm{HNCO}$ hydrolysis over $\mathrm{Al}_{2} \mathrm{O}_{3}(\mathrm{~A})$; normalized evolution of the intensity of the $\mathrm{NH}_{3}$ band at $966 \mathrm{~cm}^{-1}$ versus temperature for: $(\mathrm{O}): \mathrm{Al}_{2} \mathrm{O}_{3} ;(\square): \mathrm{WO}_{3} / \mathrm{Ce}-\mathrm{Zr} ;(\times): \mathrm{CeO}_{2}$; $(+): \mathrm{Ce}-\mathrm{Zr} ;(\diamond): \mathrm{TiO}_{2} ;(\triangle): \mathrm{ZrO}_{2}(\mathrm{~B})$.

IR surface spectra recorded over alumina sample are presented as example in Fig. S5A from $100^{\circ} \mathrm{C}$ to $175^{\circ} \mathrm{C}$. The band at $2253 \mathrm{~cm}^{-1}$ is assigned to isocyanate (-NCO) species adsorbed on $\mathrm{Al}^{3+}$ metal centre. The intensity of $-\mathrm{NCO}$ band decrease with the increase in temperature to be fully consumed at temperature higher than $150^{\circ} \mathrm{C}$. Concomitantly, gaseous $\mathrm{NH}_{3}$ and $\mathrm{CO}_{2}$ are observed in the gas phase, as the only reaction products. The intensity of the $\mathrm{NH}_{3}$ band is reported Fig. S5B versus the temperature. It appears that -NCO compounds disappears together with gaseous ammonia production. This result suggests that hydrolysis of HNCO involves adsorbed isocyanate species as intermediate. 
' W. Yang, R. Zhang, B. Chen, D. Duprez, S. Royer, Environ. Sci. Technol. 46 (2012) 11280-11288.

ii J. Liu, X. Li, Q. Zhao,C. Hao, D. Zhang, Environ. Sci. Technol. 47 (2013) 4528-4535.

iii F. Figueras, J.L. Flores, G. Delahay, A. Bourane, J.-M. Clacens, A. Desmartin-Chomel, B. Coq, A. Giroir-Fendler, Top. Catal. 39 (2006) 59-64.

iv F. Poignant, J. Saussey, J.C. Lavalley, G. Mabilon, J. Chem. Soc., Chem. Commun. (1995) 89-90.

$\checkmark$ L. Capek, K. Novoveska, Z. Sobalık, B. Wichterlova, L. Cider, E. Jobson, Appl. Catal. B 60 (2005) 201210.

${ }^{v i}$ A. Flura, X. Courtois, F. Can, S. Royer, D. Duprez, Top. Catal. 56 (2013) 94-103.

vii A.M. Bernhard, D. Peitz, M. Elsener, A. Wokaun, O. Kröcher, Appl. Catal. B., 115-116 (2012) 129-137.

viii M. Seneque, F. Can, D. Duprez, X. Courtois, ACS Catal., 6(7) (2016) 4064-4067.

${ }^{i x}$ R.A. Perry, D.L. Siebers, Nature, 1986, 324, 657-658.

${ }^{x}$ N. Apostolescu, B. Geiger, K. Hizbullah, M.T. Jan, S. Kureti, D. Reichert, F. Schott, W. Weisweiler, Appl. Catal., B., 62 (2006) 104-114.

${ }^{x i}$ G. Qi, R.T. Yang, R. Chang, Appl. Catal. B., 51 (2004) 93-106.

xii F. Can, S. Berland, S. Royer, X. Courtois, D. Duprez, ACS Catal., 3 (2013) 1120-1132.

xiii G. Larsen, E. Lotero, S. Raghavan, R.D. Parra, C.A. Querini, Appl. Catal. A., 139, 1996, 201-211.

xiv M. Tamura, K. Shimizu, A. Satsuma, Appl. Catal., 433 (2012) 135-145.

${ }^{x v}$ M.I. Zaki, M.A. Hasan, F.A. Al-Sagheer, L. Pasupulety, Colloids Surf A Physicochem Eng Asp., 190 (2001) 261-274.

xvi S. Triwahyono, T. Yamada, H. Hattori, H. Appl. Catal. A. 242 (2003) 101-109.

xvii A. Flura, F. Can, X. Courtois, S. Royer, D. Duprez, Appl. Catal. B., 126 (2012) 275-289.

xviii M.S. Lowenthal, R.K. Khanna, M.H. Moore, Spectrochim. Acta A., 58 (2002) 73-78.

xix J.H. Teles, G. Maier, B.A. Hess Jr, L.J. Schaad, M. Winnewisser, B.P. Winnewisser, Chem. Ber., 122 (1989) 753-766.

xx V.A. Matyshak and O.V. Krylov, Catal. Today, 25 (1995) 1-88.

xxi F. Solymosi and J. Raskó, J. Catal., 65 (1980) 235-237.

xxii F. Solymosi and T. Bánsági, J. Catal., 202 (2001) 205-206.

xxiii Y.H. Yeom, B. Wen, W.M.H. Sachtler, E. Weitz, J. Phys. Chem. B. 108 (2004) 5386-5404.

xxiv J. Ryczkowski, Catal Today, 68 (2001) 263-381.

xxv N. Bion, J. Saussey, M. Haneda, M. Daturi, J. Catal., 217 (2003) 47-58.

xxvi N. Bion, J. Saussey, C. Hedouin, T. Seguelong, M. Daturi, Phys. Chem. Chem. Phys., 3 (2001) 48114816.

xxvii T. Weingand, S. Kuba, K. Hadjiivanov, H. Knözinger, J. Catal., 209 (2002) 539-546.

xxviii F. Solymosi, T. Bansagi, J. Phys. Chem., 83(4) (1979) 552-553

xxix G. Halasi, T. Bánsági, F. Solymosi, J. Catal., 325 (2015) 60-67

${ }^{x \times x}$ T. Bánsági, T.S Zakar, F. Solymosi, Appl. Catal. B., 66 (2006) 147-150.

${ }^{x x x i}$ C. Binet, A. Badri and J.C. Lavalley, J. Phys. Chem., 98 (1994) 6392-6398.

xxxii S. Khabtou, T. Chevreau, J.C. Lavalley, Microporous Mater., 3 (1994) 133-148.

xxxiii C. Morterra, G. Magnacca, V. Bolis, Catal Today, 70 (2001) 43-58.

xxxiv M.L. Unland, J. Phys. Chem., 77 (1973) 1952-1956.

xxxv A.M. Berhard, D. Peitz, M. Elsener, T. Schildhauer, O. Kröcher, Catal. Sc. Technol., 3 (2013) 942951. 